\title{
SEROEPIDEMIOLOGY AND OCCUPATIONAL AND ENVIRONMENTAL VARIABLES FOR LEPTOSPIROSIS, BRUCELLOSIS AND TOXOPLASMOSIS IN SLAUGHTERHOUSE WORKERS IN THE PARANÁ STATE, BRAZIL
}

Daniela Dib GONÇALVES(1), Paulo Sérgio TELES(3), Célia Rosimarie dos REIS(1), Fabiana Maria Ruiz LOPES(1), Roberta Lemos FREIRE(2), Italmar Teodorico NAVARRO(2), Lucimara Aparecida ALVES(4), Ernest Eckehardt MULLER(2) \& Julio Cesar de FREITAS(2)

\begin{abstract}
SUMMARY
Leptospirosis, brucellosis and toxoplasmosis are widely-distributed zoonosis, being the man an accidental participant of their epidemiological chains. The aim of this paper was to make a seroepidemiological report and identify occupational and environmental variables related to these illnesses in 150 workers in a slaughterhouse in the Northern region of Paraná. For the diagnosis of leptospirosis a microscopical seroagglutination test was applied; for brucellosis, the tamponated acidified antigen test and the 2mercaptoetanol tests were used, and for toxoplasmosis the indirect immunofluorescence reaction test. For each employee an epidemiological survey was filled, which investigated occupational and environmental variables which could be associated with these infections. Positive results for leptospirosis were found in $4.00 \%$ of the samples, for brucellosis in $0.66 \%$ of samples and toxoplasmosis in $70.00 \%$. From the three diseases researched, only the results for leptospirosis suggest occupational infection.
\end{abstract}

KEYWORDS: Leptospira spp.; Brucella spp.; Toxoplasma gondii; Occupational diseases; Slaughterhouse workers.

\section{INTRODUCTION}

Occupational diseases are those which emerge through apparent or non-apparent signs and can be related, in some way, to activities executed by men in their working environment ${ }^{3}$.

Leptospirosis, brucellosis and toxoplasmosis are zoonosis of great importance to public health. These diseases affect many groups of workers which keep direct or indirect contact with animals, mainly without adequately using protection measures ${ }^{12,16,21}$.

Leptospirosis has cosmopolitan distribution and epidemiological studies have shown a clear predominance of this infection in lowremuneration professions ${ }^{16}$. In slaughterhouse workers transmission occurs through contact with urine, blood and organs from infected animals ${ }^{6,16}$.

Brucellosis is a disease which can be accidentally transmitted to men. It is widely distributed, having high morbidity and low mortality. In slaughterhouse workers, contact with infection sources can be represented by carcasses and viscera of slaughtered animals and by formation of aerosols present in the slaughtering area ${ }^{13}$.

Toxoplasmosis is also a widely distributed zoonosis which affects animals and men, being one of the parasitary infections of greatest interest to public health ${ }^{21}$. In slaughterhouse workers, the handling of carcasses and viscera from contaminated animals represent risk of infection by Toxoplasma ${ }^{21}$.

The aim of this paper was to prepare a seroepidemiological survey for leptospirosis, brucellosis and toxoplasmosis and identify occupational and environmental variables related to these illnesses in 150 workers of a slaughterhouse in the Northern region of Paraná.

\section{MATERIALS AND METHODS}

Sample collection: Blood samples were collected voluntarily from all 150 workers of a slaughterhouse with Federal Inspection Service in the Northern region of Paraná State, Brazil, which slaughtered only bovines until April, 2003 and only swine from May, 2003 onwards. All the workers wore gloves, rubber boots, waterproof aprons, helmets and masks as protection equipment. The blood collection was made by professional nurses from the local Health Center between July and September, 2003. The serological exams were performed in the Leptospirosis Laboratory, Microbiology and Infectious Diseases Laboratory and Zoonosis and Public Health Laboratory of the Department of Preventive Veterinary Medicine (DMVP), Universidade Estadual de Londrina (UEL).

Research tool: To obtain the epidemiological information, each

- Project financed by PROPPG/ProDICI-UEL/CAPES

(1) Post-Graduation Program, Animal Science, Department at Preventive Veterinarian Medicine (DMVP), Universidade Estadual de Londrina (UEL), Paraná State, Brazil.

(2) Professor at Preventive Veterinarian Medicine Department (DMVP), UEL, Paraná State, Brazil.

(3) Veterinary; Federal Inspection Service in the Northern region of Paraná State, Brazil .

(4) Biochemist of the Leptospirosis Laboratory, DMVP, UEL, Paraná State, Brazil.

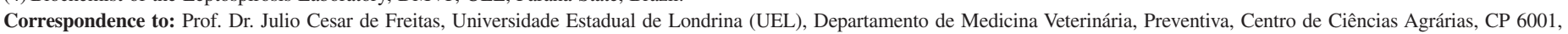
86051-990 Londrina, Paraná, Brasil, Phone/fax: 55.43.3371 4485. E-mail: freitasj@uel.br 


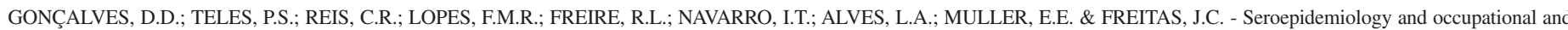
environmental variables for leptospirosis, brucellosis and toxoplasmosis in slaughterhouse workers in the Paraná State, Brazil. Rev. Inst. Med. trop. S. Paulo, 48(3):135-140, 2006.

worker was interviewed in order to fill in a questionnaire including information on occupational and environmental variables related to the studied diseases (Tables 1 and 2 and Annex 1).

Laboratory exams: Each serum sample was divided in three aliquots with equal volume, packed in sterile containers and kept at $-20^{\circ} \mathrm{C}$, for later serological analysis.

In order to detect antibodies against Leptospira spp., all sera were submitted to a microscopical seroagglutination test (SAM), using 22 reference serovars ${ }^{19}$. The sera presenting $2+$ or more in agglutination in the dilution 1:100 were considered positive, these being diluted progressively until the determination of the maximum positive dilution.

To detect antibodies against Brucella spp., all the samples were submitted to a trial test using the tamponated acidified antigen test (AAT) and as confirmatory test, the 2-mercaptoetanol (2-ME) ${ }^{1}$. The AAT test was considered positive when a macroscopic agglutination occurred and on 2-ME when there was the formation of a precipitation with film at the bottom of the tube and a clear supernatant. The sample was only considered positive when it reacted on both serologic tests.

To detect antibodies against $T$. gondii, the indirect immunofluorescence test (IFI) was performed ${ }^{4}$. All titers presenting completely fluorescent tachyzoite from titer 16 were considered as being positive.

Statistical analysis: The results obtained after the study of variables were submitted to a statistical analysis by the Chi-Square Test $\left(\chi^{2}\right)$ corrected by Yates or Fisher Test, using the statistics program Epi6 version 6.04 (CDC, Atlanta, USA), adopting a 95\% trust interval ${ }^{9}$.

\section{RESULTS}

From 150 serum samples from slaughterhouse workers analyzed, six $(4.00 \%)$ were considered positive for leptospirosis, one $(0.66 \%)$ for brucellosis and $105(70.00 \%)$ for toxoplasmosis. Four samples $(66.67 \%)$ presented antibodies only against one Leptospira serovar and two samples $(33.33 \%)$ against two serovars simultaneously. Antibodies against serovars Hardjo, Wolffi and Castellonis were found, with titers between 100 and 400. The positive serum samples were from three employees from the waxing sector, one from the slaughtering room, one who operated machines and one from the animal and packages loading sector. The analysis of the variables indicated the living in an urban zone $(\mathrm{p}=0.033)$ as a risk factor for leptospirosis (Table 1). For brucellosis, only one sample $(0.66 \%)$ was considered positive, presenting agglutination on the AAT test and titer of 100 on 2-ME. This sample belongs to a worker in the administrative sector. In relation to toxoplasmosis, 105 samples $(70.00 \%)$ were considered positive to IFI, with titers varying from 16 to 4096 . These samples were from 63 workers from the slaughter room, six from the inspection room, five from the cauldron, 27 from general services and four from the office. There were no statistically significant differences among the variables studied and the presence of T. gondii (Table 2).

\section{DISCUSSION}

The percentage of workers in the slaughterhouse with positive
Table 1

Results of Fisher test in relation to the variables analyzed in order to determine the risk factors for leptospirosis in 150 serum samples of workers in a slaughterhouse with Federal Inspection Service of the Northern region of Paraná

\begin{tabular}{|c|c|c|}
\hline Variables & $\begin{array}{l}\text { Positive } \\
\text { samples / n (\%) }\end{array}$ & $\mathrm{p}^{*}$ \\
\hline \multicolumn{3}{|l|}{ Sex } \\
\hline Feminine & $0 / 37(0.00)$ & 0.336 \\
\hline Masculine & $6 / 113(5.30)$ & \\
\hline \multicolumn{3}{|l|}{ Living } \\
\hline Urban zone & $2 / 8(25.00)$ & 0.033 \\
\hline Peri-urban / rural zone & $4 / 142(2.81)$ & \\
\hline \multicolumn{3}{|c|}{ Presence of pets at home } \\
\hline Yes & $4 / 110(3.63)$ & 0.657 \\
\hline No & $2 / 40(5.00)$ & \\
\hline \multicolumn{3}{|c|}{ House with sewage system } \\
\hline Public service & $4 / 140(2.85)$ & 0.052 \\
\hline Septic tank & $2 / 10(20.00)$ & \\
\hline \multicolumn{3}{|c|}{ Abandoned plot near the house } \\
\hline Yes & $3 / 72(4.16)$ & 1.000 \\
\hline No & $3 / 78(3.84)$ & \\
\hline \multicolumn{3}{|c|}{ Presence of rodents at home } \\
\hline Yes & $3 / 88(3.40)$ & 0.691 \\
\hline No & $3 / 62(4.83)$ & \\
\hline \multicolumn{3}{|c|}{$\begin{array}{l}\text { Direct contact with blood/organs } \\
\text { in slaughterhouse }\end{array}$} \\
\hline Yes & 4/111 (3.60) & 0.650 \\
\hline No & $2 / 39(5.12)$ & \\
\hline \multicolumn{3}{|c|}{ Suffered work-related accident } \\
\hline Yes & $3 / 86(3.48)$ & 0.700 \\
\hline No & $3 / 64(4.68)$ & \\
\hline \multicolumn{3}{|c|}{ Habitude of eating during work } \\
\hline Yes & $5 / 145(3.44)$ & 0.186 \\
\hline No & $1 / 5(20.00)$ & \\
\hline \multicolumn{3}{|c|}{$\begin{array}{l}\text { Habitude of washing hands before/ } \\
\text { after eating during work }\end{array}$} \\
\hline Yes & $6 / 140(4.28)$ & 1.000 \\
\hline No & $0 / 10(0.00)$ & \\
\hline \multicolumn{3}{|c|}{ Contact with urine on inspection table } \\
\hline Yes & $2 / 40(5.00)$ & 0.657 \\
\hline No & $4 / 110(3.63)$ & \\
\hline \multicolumn{3}{|l|}{ Previous work in farms } \\
\hline Yes & $6 / 107(5.60)$ & 0.182 \\
\hline No & $0 / 43(0.00)$ & \\
\hline \multicolumn{3}{|l|}{ Helped animal births } \\
\hline Yes & $3 / 26(11.53)$ & 0.064 \\
\hline No & $3 / 124(2.41)$ & \\
\hline \multicolumn{3}{|l|}{ Muscular pain } \\
\hline Yes & $3 / 96(3.12)$ & 0.667 \\
\hline No & $3 / 54(5.55)$ & \\
\hline
\end{tabular}

Fisher's exact test - probability

serological results for leptospirosis was of $4.00 \%$. These results were higher than those found in Minas Gerais State, Brazil ${ }^{17}$, São Paulo State, Brazil $^{7}$ and in Turkey ${ }^{2}$ which described, respectively, 2.70\%; $2.95 \%$ and 


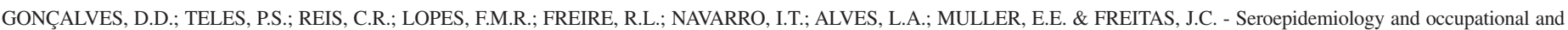
environmental variables for leptospirosis, brucellosis and toxoplasmosis in slaughterhouse workers in the Paraná State, Brazil. Rev. Inst. Med. trop. S. Paulo, 48(3):135-140, 2006.

Table 2

Results from Chi-square test $\left(\chi^{2}\right)$ in relation to variables analyzed to determine risk factors for toxoplasmosis in 150 serum samples in workers of a slaughterhouse with Federal Inspection Service in the Northern region of Paraná

\begin{tabular}{|c|c|c|c|}
\hline Variables & $\begin{array}{l}\text { Positive } \\
\text { samples / n (\%) }\end{array}$ & $\chi^{2}$ & $\mathrm{p}$ \\
\hline \multicolumn{4}{|l|}{ Sex } \\
\hline Feminine & $25 / 37(67.56)$ & 0.03 & 0.868 \\
\hline Masculine & $80 / 113(70.79)$ & & \\
\hline \multicolumn{4}{|l|}{ Living } \\
\hline Urban zone & $6 / 8(75.00)$ & - & $1.000 *$ \\
\hline Peri-urban / rural zone & $99 / 142(69.01)$ & & \\
\hline \multicolumn{4}{|c|}{ House with sewage system } \\
\hline Public service & $98 / 140(70.00)$ & - & $1.000 *$ \\
\hline Septic tank & $7 / 10(70.00)$ & & \\
\hline \multicolumn{4}{|c|}{ Presence of rodents at home } \\
\hline Yes & $60 / 88(68.18)$ & 0.16 & 0.690 \\
\hline No & $45 / 62(72.58)$ & & \\
\hline \multicolumn{4}{|c|}{ Presence of pets at home } \\
\hline Yes & $77 / 110(70.00)$ & 0.04 & 0.840 \\
\hline No & 28/40 (70.00) & & \\
\hline \multicolumn{4}{|c|}{$\begin{array}{l}\text { Direct contact with blood/ } \\
\text { organs in slaughterhouse }\end{array}$} \\
\hline Yes & 76/111 (68.46) & 0.24 & 0.625 \\
\hline No & $29 / 39(74.35)$ & & \\
\hline \multicolumn{4}{|c|}{ Suffered work-related accident } \\
\hline Yes & $66 / 86(76.74)$ & 3.65 & 0.056 \\
\hline No & $39 / 64(60.93)$ & & \\
\hline \multicolumn{4}{|c|}{$\begin{array}{l}\text { Habitude of washing fruit/ } \\
\text { vegetables before consumption }\end{array}$} \\
\hline Yes & $102 / 145(70.34)$ & - & $0.636^{*}$ \\
\hline No & $3 / 5(60.00)$ & & \\
\hline \multicolumn{4}{|c|}{ Habitude of handling soil } \\
\hline Yes & 75/109 (68.80) & 0.10 & 0.749 \\
\hline No & $30 / 41(73.17)$ & & \\
\hline \multicolumn{4}{|c|}{ Habitude of ingesting raw /rare meat } \\
\hline Yes & $49 / 65(75.38)$ & 1.16 & 0.280 \\
\hline No & $56 / 85(65.88)$ & & \\
\hline \multicolumn{4}{|c|}{ Habitude of ingesting raw milk } \\
\hline Yes & $93 / 132(70.45)$ & 0.00 & 0.956 \\
\hline No & $12 / 18(66.66)$ & & \\
\hline \multicolumn{4}{|c|}{ Previous work in a farm } \\
\hline Yes & 74/107 (69.15) & 0.02 & 0.874 \\
\hline No & $31 / 43(72.09)$ & & \\
\hline \multicolumn{4}{|l|}{ Muscular pain } \\
\hline Yes & 64/96 (66.66) & 1.00 & 0.316 \\
\hline No & $41 / 54(76.34)$ & & \\
\hline
\end{tabular}

$\mathrm{p}=$ probability $*$ * Fisher's exact test

$1.96 \%$ positivity among the employees from the slaughterhouses studied. The different results obtained could have been influenced by the difference in the prevalence of animal leptospirosis in the respective regions and countries studied and could also reflect the periods studied, which leads to higher or lower probabilities of infection in workers who handle carcasses, organs and viscera from animals infected with different serovars of Leptospira. Antibodies against serovars Hardjo, Wolffi and Castellonis with titers between 100 and 400 were found. Similar results in titers and antibodies against serovars were obtained in São Paulo State, Brazil $^{6}$ and Colombia ${ }^{18}$. The serological results of this paper suggest these workers had already had contact with some Leptospira serovars and probably been infected for some time. The low serological titers found on the workers, associated with the antibodies detected against the serovars traditionally related to cattle, suggest chronic infections occurring when this slaughterhouse worked only with bovines. In relation to the different sectors of the slaughterhouse, from six positive employees in MAT, three $(50.00 \%)$ worked in the waxing sector. These results are similar to those found in workers in the same sector in Minas Gerais State, Brazil and S. Paulo State, Brazil, also with $50.00 \%$ positivity ${ }^{20}$. These results confirm this sector as having a high infection risk due to the exposure of organs and viscera of possibly infected animals. Despite leptospirosis being an occupational disease in slaughterhouse workers, the occupational variables analyzed were not significant. However, we should not discharge the possibility of this infection having occurred by other environmental and behavioral situations, once that, even though the variable living in urban zone $(\mathrm{p}=0.033)$ was being considered as a risk factor, the infection could have occurred in the working environment, when the slaughterhouse still killed only bovines.

For brucellosis, one sample was considered positive $(0.66 \%)$ on both serological tests. This employee worked in administration and did not have direct contact with the animals. However, he had the habit of ingesting non-pasteurized milk, which could indicate the probable source of infection. This low prevalence of human brucellosis among the slaughterhouse workers researched in this paper is probably related with the low prevalence $(3.02 \%)$ of bovine brucellosis in the State of Paraná, Brazil ${ }^{10}$.

The 105 (70.00\%) employees who were found positive for toxoplasmosis indicate that the infection by this microorganism is still in high levels when compared to others in the region studied. In Jaguapitã, Paraná State, Brazil ${ }^{14}$ the prevalence of human toxoplasmosis is of $66.00 \%$ seroreagents. In Londrina, Paraná State, Brazil ${ }^{11}$ a positivity of $59.50 \%$ was detected in employees of a pork sausage factory and in Pato Branco, Paraná State, Brazil ${ }^{8}$ a positivity of $67.20 \%$ among workers of slaughterhouses. The titers of antibodies found by IFI in this paper varied from 16 to 4096, with 11 (10.48\%) employees presenting titers of 4096, suggesting recent infection by $T$. gondii. The sector of the slaughterhouse which had most workers affected was the inspection room, with $75.00 \%$ positivity, followed by the slaughtering room, with $70.00 \%$. However, there were no statistically significant differences among the sectors, suggesting the infection also occurred in an external environment, not only in the working environment. Despite toxoplasmosis being considered an occupational disease, the occupational variables analyzed in this study were of no significance. Among the three diseases studied in this work, it is possible that the infection of the workers by Leptospira spp. had occupationally occurred, despite the variable living in urban zone $(\mathrm{p}=0.033)$ having been considered as a risk factor, while the infections by Brucella spp. and $T$. gondii occurred probably outside working environment.

ETHICS COMMITTEE: The present paper was approved by the Ethics in Research Committee of the Hospital Universitário Regional do Norte do Paraná, Decision CEP 142/03. 


\section{ANNEX 1}

\section{EPIDEMOLOGY SURVEY: LEPTOSPIROSIS, BRUCELLOSIS AND TOXOPLASMOSIS IN SLAUGHTERHOUSE WORKERS}

- RESIDENCE: rural area ( ) urban area ( )

\section{- EDUCATION:}

- Elementary School

- High School

complete ( )
incomplete ( )
complete ( )
incomplete ( )
incomplete ( )

- University

\section{- ANIMALS:}

- Do you have pets at home? yes ( ) no ( ) canine ( ) feline ( )

- Do the pets have contact with other animals? yes ( ) no ( )

- Has the pet been sick? yes ( ) no ( )

- If yes, what were the symptoms?.....

- Does the pet have access to the house? yes ( ) no ( )

- In case you have cats, where do they defecate? home ( ) yard ( ) litter box ( )

- Which of the following does the pet have contact with? vegetable gardens ( ) flower gardens ( ) garbage ( ) vacant lots ( ) flooded areas ( )

\section{- WATER SUPPLY:}

- Does the house have treated water? yes ( ) no ( )

- Is the water tank covered? yes ( ) no ( )

\section{- SEWAGE:}

- Destination? public sewage system ( ) cesspit ( ) river/streams ( ) in the open ( )

\section{- GARBAGE:}

- Destination? public collection system ( ) vacant lots ( )

- Garbage storage? plastic bags ( ) open bins ( )

- Does the pet have access to the house and/or street garbage? yes ( ) no ( )

\section{- VACANT LOTS:}

- Are there vacant lots next to the house? yes ( ) no ( )

- Is there garbage in the lot? yes ( ) no ( )

\section{- FLOODED AREAS:}

- Is there a stream next to the house? yes ( ) no ( )

\section{- RODENTS:}

- Are rodents found in the house? yes ( ) no ( )

- Are rodent prevention mechanisms being used? yes ( ) no ( ) 


\section{SLAUGHTERHOUSE WORK:}

- Sector?.

- How long have you worked in this sector? 1 year ( ) 3 years ( ) 5 years ( ) 10 years ( ) more than 10 years ( )

- Do you have any contact with animal organs, muscles, blood? yes ( ) no ( )

- Which sector did you work for before?

- How long did you work in this sector? 1 year ( ) 3 years ( ) 5 years ( ) 10 years ( ) more than 10 years ( )

- Did you receive any training before you started working? yes ( ) no ( )

- Do you wear? gloves ( ) rubber boots ( ) waterproof aprons ( ) masks ( ) protection glasses ( )

- Have you had any work-related accident? yes ( ) no ( )

- What happened?

- Where did you work before you started working for the slaughterhouse?.

- How long did you work there?.

- Do you smoke? yes ( ) no ( )

- Do you smoke during your work breaks? yes ( ) no ( )

- Do you wash your hands before and after you smoke? yes ( ) no ( )

- Do you eat during working hours? yes ( ) no ( )

- Do you eat during your work breaks? yes ( ) no ( )

- Do you wash your hands before and after you eat? yes ( ) no ( )

- Do you have any contact with urine in the inspection table? yes ( ) no ( )

\section{BEHAVIORAL HABITUDES:}

- Do you fish or bathe in rivers? lakes ( ) dams ( ) dikes ( )

- Do you carry out activities related to soil or sand manipulation? yes ( ) no ( )

- Do you keep animal food at home? yes ( ) no ( )

- Is the animal food kept in the open? yes ( ) no ( )

- Do you usually wash fruits and vegetables before you eat them? yes ( ) no ( )

- Eating habitudes: raw/rare meat ( ) home made cheese ( ) non-pasteurized milk ( )

- Have you had any blood transfusion? yes ( ) no ( )

- Have you ever worked on farms or small rural properties? yes ( ) no ( )

- If yes, for how long?.

- Do you own a place in the country or a small rural property? yes ( ) no ( )

- If yes, do you raise animals in the property? yes ( ) no ( )

- If yes, which animals do you raise? bovine ( ) caprine ( ) swine ( ) poultry ( )

- Have you ever participated in vaccinations? yes ( ) no ( )

- Have you ever had any infectious disease (hepatitis, leptospirosis, toxoplasmosis, brucellosis)? yes ( ) no ( )

- Did you have any cold symptoms? a week ago ( ) 15 days ago ( ) a month ago ( ) 3 months ago ( )

6 months ago ( ) more than 6 months ago ( )

- If yes, which of these symptoms did you have? fever ( ) muscle pain ( ) headache ( ) ? weight loss ( ) bleeding ( ) dry cough ( ) diarrhea ( ) sweating ( ) shivering ( ) insomnia ( ) calf pain ( ) arthralgia ( ) - Do you have any children with some kind of deficiency? yes ( ) no ( ) physical ( ) mental ( )

- Are you familiar with the diseases that can be transmitted by animals? yes ( ) no ( ) Which ones? 


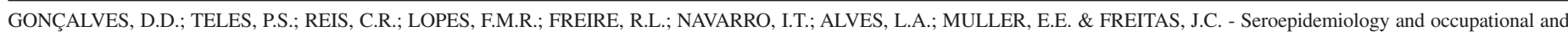
environmental variables for leptospirosis, brucellosis and toxoplasmosis in slaughterhouse workers in the Paraná State, Brazil. Rev. Inst. Med. trop. S. Paulo, 48(3):135-140, 2006.

\section{RESUMO}

\begin{abstract}
Soroepidemiologia e variáveis ocupacionais e ambientais relacionadas à leptospirose, brucelose e toxoplasmose em trabalhadores de frigorífico do Estado do Paraná, Brasil
\end{abstract}

A leptospirose, brucelose e a toxoplasmose são zoonoses de ampla distribuição, sendo o homem participante acidental das suas cadeias epidemiológicas. O objetivo deste trabalho foi realizar levantamento soroepidemiológico e identificar variáveis ocupacionais e ambientais relacionadas a estas enfermidades em 150 trabalhadores de um frigorífico da região Norte do Paraná. Para o diagnóstico de leptospirose foi realizada a prova de soroaglutinação microscópica; para a brucelose, a prova do antígeno acidificado tamponado e do 2-mercaptoetanol e para toxoplasmose, a reação de imunofluorescência indireta. Para cada funcionário foi preenchido um questionário epidemiológico que investigou variáveis ocupacionais e ambientais que poderiam estar associadas a estas infecções. Resultados positivos para leptospirose foram encontrados em 4,00\% das amostras, para brucelose em 0,66\% das amostras e para toxoplasmose 70,00\%. Das três enfermidades pesquisadas, somente os resultados obtidos para leptospirose sugerem infecção de modo ocupacional.

\section{ACKNOWLEDGEMENTS}

The authors would like to thank the workers of the slaughterhouse and the Health Center for their attention and constant collaboration.

\section{REFERENCES}

1. ALTON, G.G.; JONES, L.M.; ANGUS, R.D. \& VERGER, J.M. - Techniques for the brucellosis laboratory. Paris, Institut National de la Recherche Agronomique, 1988.

2. BABÜR, C.; ÖZDEMIR, V.; KILIC, S.; EROL, E. \& ESEN, B. - Anti-Leptospira antibodies in slaughterhouse workers in Ankara. Mikrobiyol. Bül., 37: 143-150, 2003.

3. BRASIL, 2005. http://portal.saude.gov.br/saude/

4. CAMARGO, M.E. - Introdução às técnicas de imunofluorescência. Rev. bras. Pat. clín., 10: 143-171, 1973.

5. CAMARGO, M.C.V.; ANTUNES, C.M.F. \& CHIARI, C.A. - Epidemiologia da infecção por Toxoplasma gondii no município de Ribeirão das Neves, MG. I. Importância dos animais domésticos como fonte de infecção do T. gondii para o homem. Rev. Soc. bras. Med. trop., 28: 211-214, 1995.

6. CARVALHO, A.C.F.B.; ÁVILA, F.A. \& GÍRIO, R.J.S. - Infecção leptospírica em manipuladores de carne na região de Ribeirão Preto, São Paulo. Arq. vet., 1: 77-81, 1985 .

7. CASTRO, A.F.P.; SANTA ROSA, C.A.; ALMEIDA, W.F. \& TROISE, C. - Pesquisa de aglutininas anti-Leptospira entre magarefes em alguns municípios do Estado de São Paulo. Rev. Inst. Med. trop. S. Paulo, 8: 287-290, 1966.
8. DAGUER, H.; VICENTE, R.T.; COSTA, T. et al. - Soroprevalência de anticorpos antiToxoplasma gondii em bovinos e funcionários de matadouros da microregião de Pato Branco, Paraná, Brasil. Ciênc. rural, 34: 1133-1137, 2004.

9. DEAN, A.G.; DEAN, J.A.; COULOMERIER, D. et al. - Epi Info, Version 6: a word processing, data bases, and statistic program for epidemiology on microcomputers. Atlanta, Centers for Disease Control and Prevention, 1994.

10. DIAS, J.A. - Prevalência e distribuição geográfica da brucelose bovina e bubalina no Estado do Paraná, Brasil. Londrina, 2003. (Dissertação de Mestrado - Faculdade de Medicina Veterinária da Universidade Estadual de Londrina).

11. DIAS, R.A.F.; NAVARRO, I.T.; RUFFOLO, B.B. et al. - Toxoplasma gondii in fresh pork sausage and seroprevalence in butchers from factories in Londrina, Paraná State, Brasil. Rev. Inst. Med. trop. S. Paulo, 47: 185-189, 2005.

12. FIGUEIREDO, B.L. - Brucelose como doença ocupacional. I. Aglutininas anti Brucella sp. em grupos ocupacionais dos frigoríficos da grande Belo Horizonte. Arq. bras. Med. vet. Zoot., 37: 385-407, 1985.

13. FREITAS, J.A.; GALINDO, G.A.R.; SANTOS, E.J.C.; SARRAF, K.A. \& OLIVEIRA, J.P. - Risco de brucelose zoonótica associado a suínos de abate clandestino. Rev. Saúde públ. (S. Paulo), 35: 101-102, 2001.

14. GARCIA, J.L.; NAVARRO, I.T.; OGAWA, L.; OLIVEIRA, R.C. \& KOBILKA, E. Soroprevalência, epidemiologia e avaliação ocular da toxoplasmose humana na zona rural de Jaguapitã (Paraná), Brasil. Rev. panamer. Salud públ., 6: 157-163, 1999.

15. IBRAHIM, B.B.; SALAMA, M.M.; GANWISH, N.I. \& HARIDY, F.M. - Serological and histopathological studies on Toxoplasma gondii among the workers and the slaughtered animal in Tanta Abattoir, Gharbia Governorate. J. Egypt. Soc. Parasit., 27: 273-278, 1997.

16. LEVETT, P.N. - Leptospirosis. Clin. Microbiol. Rev., 14: 296-326, 2001.

17. NOHMI, N. - Contribuição à epidemiologia das leptospiroses. Hospital (Rio de J.), 65: 167-181, 1964.

18. ORREGO URIBE, A.; GIRALDO DE LEON, G.; RIOS ARANGO, B. \& VALENCIA PRADA, P.A. - Leptospirosis en personas de riesgo de quince explotaciones porcinas y de la central de sacrifício de Manizales, Colombia. Arch. Med. vet. (Valdívia), 35: 205-213, 2003.

19. RYU, E. - Rapid microscopic agglutination test for Leptospira without non-specific reaction. Bull. Off. int. Epizoot., 20: 285-292, 1970.

20. SANTA ROSA, C.A.; COSCINA, A.L.; CASTRO, A.F.P.; SILVA, A.S. \& QUEIROZ, J.C. - Pesquisa de aglutininas anti-Leptospira em soros de trabalhadores de diversas profissões. Rev. Microbiol. (S. Paulo), 1: 19-24, 1970.

21. TENTER, A.M.; HECKEROTH, A.R. \& WEISS, L.M. - Toxoplasma gondii: from animals to humans. Int. J. Parasit., 30: 1217-1258, 2000.

Received: 20 October 2005

Accepted: 20 February 2006 